\title{
The Potential of Chemical and Spectroscopy Characterization in the Analysis and Classification of Horizons From Tropical Soil
}

\author{
Carra, J. B.; Fabris, M.; Santos-Tonial, L. M.*
}

Rev. Virtual Quim., 2017, 9 (5), 1813-1824. Data de publicação na Web: 24 de julho de 2017

\author{
http://rvq.sbq.org.br
}

\section{O Potencial da Caracterização Química e Espectroscópica na Análise e Classificação dos Horizontes de Solos Tropicais}

\begin{abstract}
Resumo: Este estudo avaliou as características químicas e espectroscópicas para contrastar a Classificação Brasileira de solos para um Latossolo Bruno. As amostras de solo dos horizontes $A, A B, B A$ e $B$ do Latossolo Bruno analisadas foram coletadas em Abelardo Luz, Santa Catarina, Brasil. A fração de ácido húmico foi obtida por fracionamento químico. As amostras de solo e de ácido húmico foram caracterizadas por espectroscopia de infravermelho com Transformada de Fourier, espectroscopia de absorção ultravioleta visível e microscopia eletrônica de varredura. O teor de carbono foi determinado por combustão seca. As características espectroscópicas da matéria orgânica presente nas amostras indicam que as mudanças não são claras como as observadas por parâmetros utilizados no sistema brasileiro de classificação de solos. Assim, estes resultados sugerem que a análise qualitativa, grau de aromaticidade e índice de humificação não podem contribuir para a classificação pedológica do solo. A variação gradual do teor de carbono, com a profundidade do solo, está de acordo com o esperado uma vez que os resíduos são incorporados no solo desta maneira. No total, os resultados revelam que, apesar dos parâmetros analisados não contribuírem no estudo de classificação de solos, estes fornecem informações importantes sobre a matéria orgânica do solo.
\end{abstract}

Palavras-chave: Análises Multivariadas; Grau de Aromaticidade; Índice de Humificação; Latossolo; Teor de Carbono.

\begin{abstract}
This study assessed the chemical and spectroscopic characteristics to contrast the Brazilian Soil Classification System for Latossolo Bruno. The soil samples of $A, A B, B A$ and $B$ horizons from Latossolo Bruno analyzed in this study were collected in Abelardo Luz, Santa Catarina state, Brazil. The humic acid fraction was obtained by chemical fractionation. The soil and humic acid samples were characterized by Fourier transform infrared spectroscopy, ultraviolet visible absorption spectroscopy and scanning electron microscopy. The carbon content was determined by dry combustion. The organic matter spectroscopic characteristics of the $A, A B, B A$ and $B$ horizons from Latossolo Bruno indicate that the changes are not as clear as those observed by parameters used in the Brazilian Soil Classification System. Thus, these results suggest that the qualitative analysis, aromaticity degree and humification index cannot contribute to the pedological classification of soils. The gradual variation in carbon content with soil depth occurred as expected, since the residues are incorporated into the soil in this manner. Altogether, the results reveal that despite the fact that the parameters analyzed did not contribute to soil classification, the study of these parameters provide important information about the soil organic matter.
\end{abstract}

Keywords: Aromaticity degree; Carbon content; Humification index; Multivariate analysis; Oxisol.

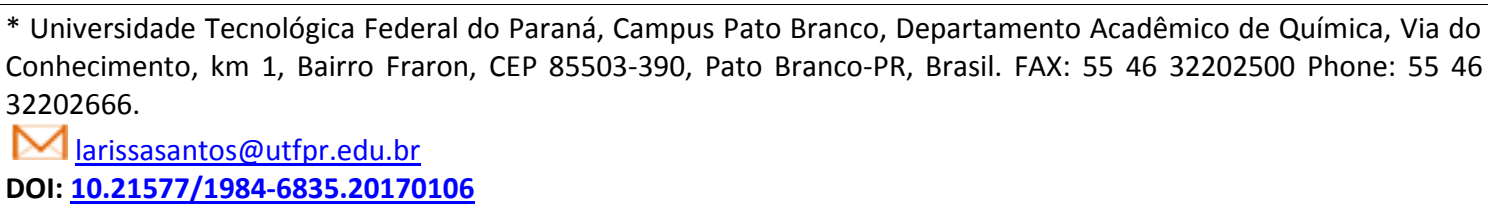




\section{The Potential of Chemical and Spectroscopy Characterization in the Analysis and Classification of Horizons From Tropical Soil}

\section{Jéssica B. Carra, Marcieli Fabris, Larissa M. Santos-Tonial*}

Universidade Tecnológica Federal do Paraná, Campus Pato Branco, Departamento Acadêmico de Química, Via do Conhecimento, km 1, Bairro Fraron, CEP 85503-390, Pato Branco-PR, Brasil.

* larissasantos@utfpr.edu.br

Recebido em 13 de setembro de 2016. Aceito para publicação em 21 de junho de 2017

\section{Introduction}

\section{Materials and Methods}

\subsection{Experimental area}

2.2. Soil sample collection

2.3. Sample Preparation

2.4. Chemical Fractionation

2.5. Total Carbon

2.6. Spectroscopy Characterization

2.7. Humification index

2.8. SEM

2.9. Multivariate analysis

\section{Results and Discussion}

\section{Conclusions}

\section{Introduction}

The classification is a basic requirement of all science. Within the soil science scope, the classification contributes to the understanding of soil properties such as texture, structure, density, porosity, permeability, among others. Currently, there are several soil rating systems such as the FAO international system, ${ }^{1}$ the American Soil Taxonomy Classification, ${ }^{2}$ the Australian Soil Classification $^{3}$ and the Brazilian Soil Classification System. ${ }^{4}$
However, despite the several soil classification systems, the Soil Map of the World $^{1}$ synthesizes the distribution and characteristics of the world's soils, classifying the soils through the use of parameters such as horizons, abrupt textural change, calcareous, continuous hard rock, organic soil materials and others.

According to Soil Taxonomy, ${ }^{2}$ soil is composed of solid minerals and organic matter, and is characterized by horizons and transformations of energy and matter, or the ability to support rooted plants in a natural environment. The Brazilian Soil Classification 
System classifies the soil using information such as the presence or absence of certain attributes (clay fraction activity, organic material, mineral material, base saturation, among others), horizons, minerals and morphological characteristics, in addition to general properties that can be recognized in the soil. ${ }^{4}$

Thus, soil classification is fundamental and needs to be reviewed periodically. Due to the soil to be a constantly changing natural multivariable system, and due to the emergence of new characterization techniques, the present work suggests that parameters commonly employed in soil characterization such as, Scanning Electron Microscopy $(\mathrm{SEM})^{5}$, Fourier transform infrared spectroscopy (FTIR), carbon content ${ }^{6}$ and ultraviolet (UV)-visible absorption spectroscopy, ${ }^{7}$ are referenced in the Brazilian soil classification manual, be evaluated.

In this context, the objective of the present study was to characterize by chemical and spectroscopic methods, soils and humic acid (HA) samples of $A, A B, B A$ and $B$ horizons from Latossolo Bruno, and coupled with statistical treatment, to determine there are significant differences in the chemical composition of horizons. Our hypothesis is that the qualitative and quantitative results coupled with chemometric methods will help in the soils pedological classification.

\section{Materials and Methods}

\subsection{Experimental area}

The experimental area is a private rural property, Pacheco Farm, in the city of Abelardo Luz, Santa Catarina state, Brazil $\left(26^{\circ} 31^{\prime} 29,67^{\prime \prime} \mathrm{S},-52^{\circ} 15^{\prime} 35,17^{\prime \prime} \mathrm{W}\right.$ and $851 \mathrm{~m}$ altitude).

\subsection{Soil sample collection}

Soil samples were collected in August, 2014 and were classified as a Latossolo Bruno, according to the Brazilian Soil Classification System. ${ }^{4}$ A trench with 1.00 wide versus $2.00 \mathrm{~m}$ depth trenches was opened where 1 samples was collected in each horizon. The horizons $A(0-0.39 \mathrm{~m}), A B$ (0.40-0.51 m), BA (0.52-1.05 m) and $B(1.06-$ $2.00 \mathrm{~m}$ ) were characterized according to the color, structure, consistency, plasticity and stickiness.

\subsection{Sample Preparation}

After collection, the samples were dried in an oven at $40{ }^{\circ} \mathrm{C}$ and later ground in a TE-330 hammer mill (Tecnal), and sieved ( $2 \mathrm{~mm}$ ).

\subsection{Chemical Fractionation}

The HA fraction was extracted following the methodology suggested by the International Humic Substance Society (IHSS). ${ }^{8}$

\subsection{Total Carbon}

The total carbon contents of the soil samples were determined on $0.5 \mathrm{mg}$ of sample by dry combustion, using a Eurovector 3000 elemental analyzer (Milan, Italy). The procedure was accomplished in triplicate for each soil sample.

\subsection{Spectroscopy Characterization}

FTIR spectra from soil and HA fraction were acquired using a Frontier spectrophotometer (Perkin Elmer, USA) equipped with a $\mathrm{KBr}$ beam splitter and DTGS detector. Spectra were collected in the $\mathrm{KBr}$ transmission mode $(1.5 \mathrm{mg}$ sample: $150 \mathrm{mg}$ $\mathrm{KBr}$ ) over a range of $4000-400 \mathrm{~cm}^{-1}$ by coadding 64 scans at a resolution of $4 \mathrm{~cm}^{-1}$, 
according to Stevenson (1994) and Merlin et al. (2015). ${ }^{9,10}$

UV-visible spectra from HA were acquired according to Chen et al. (1977) ${ }^{11}$ using a spectrophotometer model SP-22 (Bioespectro, Brazil).

\subsection{Humification index}

The humification index was determined using two approaches. In the first, the humification index was determined from the aromaticity degree $\left(\mathrm{I}_{1630} / \mathrm{I}_{2920}\right)$, which is based on the ratio of the absorption intensity at $1630 \mathrm{~cm}^{-1}$ (corresponding to the aromatic groups) and $2920 \mathrm{~cm}^{-1}$ (corresponding to the aliphatic groups). ${ }^{12}$

The second, the $E_{4} / E_{6}$ ratio was determined using the ratio between the absorbance at 465 and $665 \mathrm{~nm}\left(\mathrm{E}_{4} / \mathrm{E}_{6}\right)$, as suggested by Chen et al. $1977 .{ }^{11}$

Usually humification process is evaluated by making indirect measurements that describe structural changes that occur during the humification process. In this work the humification index was indirectly indicate by $\mathrm{I}_{1630} / \mathrm{I}_{2920}$ and $\mathrm{E}_{4} / \mathrm{E}_{6}$ ratios.

FTIR and UV-visible spectra were acquired using the same parameters applied in the spectroscopy characterization. In order to obtain the FTIR aromaticity index, two spectra replicates were acquired.

\subsection{SEM}

The $A, A B, B A$ and $B$ horizons of the soil were examined using a Hitachi TM 3000 table top SEM operating at $15 \mathrm{kV}$.

\subsection{Multivariate analysis}

Multivariate analysis was evaluated using Pirouette software (version 4.0, Infometrix Inc., Woodville, WA, USA). Principal component analysis (PCA) models were developed in order to obtain a global view of the main variation in the data set. These models were evaluated using the results obtained from FTIR. Before the analysis, the data were mean-centered and the first derivative, second derivative, standard normal variate method (SNV) and baseline correction were evaluated.

\section{Results and Discussion}

FTIR spectra from soil and HA samples are shown in Figures $1 a$ and $1 b$, respectively.

Qualitative analysis of the FTIR spectra from soils (Figure 1a) and HA (Figure 1b) were based in Brinatti et al. 2010, ${ }^{13}$ Tivet et al. $2013,{ }^{14}$ Benites et al. 1999, ${ }^{15}$ and Castellano et al. 2010. ${ }^{16}$ Table 1 presents FTIR spectra show bands at the following frequencies.

The occurrence of peaks between 3697 and $3445 \mathrm{~cm}^{-1}$ in the spectra (Figure 1) indicates the presence of mineral impurities, kaolinite, halloysite and gibbsite, in these samples. ${ }^{13,14}$ Other evidence of mineral impurities are: the signal at 1047, 1010, 915, $798,747,692$ and $430 \mathrm{~cm}^{-1} \cdot{ }^{13,14,16}$ The signal characteristic from axial deformation in phenolic $\mathrm{O}-\mathrm{H}$ group, with aliphatic $\mathrm{O}-\mathrm{H}$ contribution, $\mathrm{H}_{2} \mathrm{O}$ and amine can not be clearly observed. The signals around at 1630 $\mathrm{cm}^{-1}$ are characteristic of aromatic $\mathrm{C}=\mathrm{C}$ vibrations and asymmetrical stretching $\mathrm{C}=\mathrm{O}$ of $\mathrm{COO}^{-}$and are more intense in the spectra of humic acid. The signals at 1462 and 1423 $\mathrm{cm}^{-1}$ presented low intensity when compared to the signal around $1630 \mathrm{~cm}^{-1}$. In the soil and HA spectra no signals centered on 2922 $\mathrm{cm}^{-1}$ and $2852 \mathrm{~cm}^{-1}$. ${ }^{14}$ 
(a)

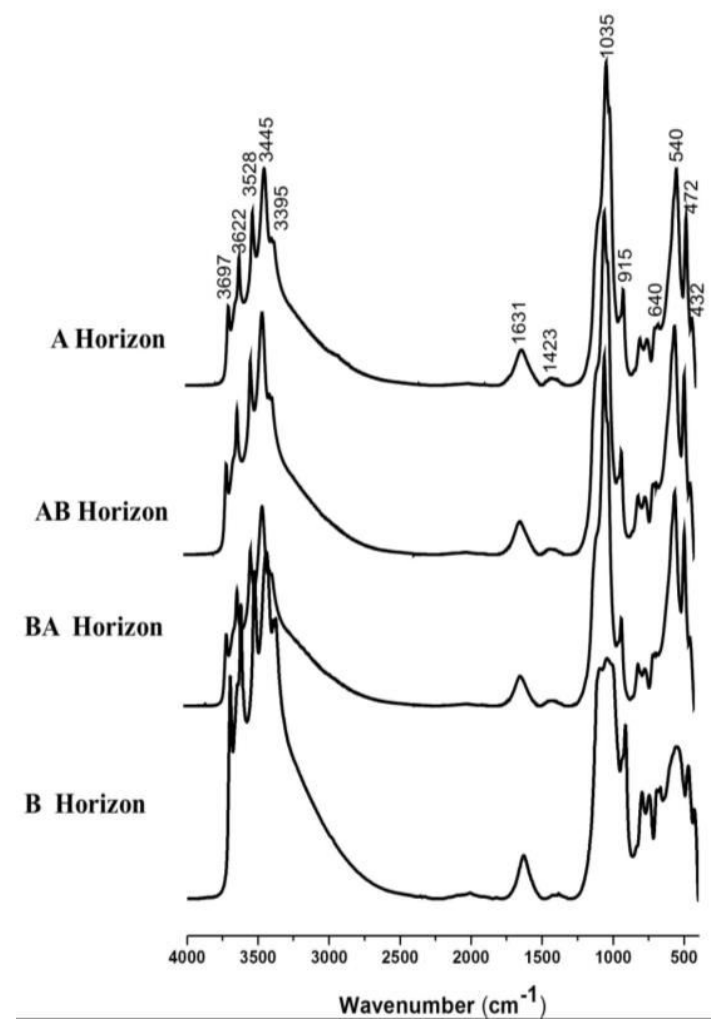

(b)

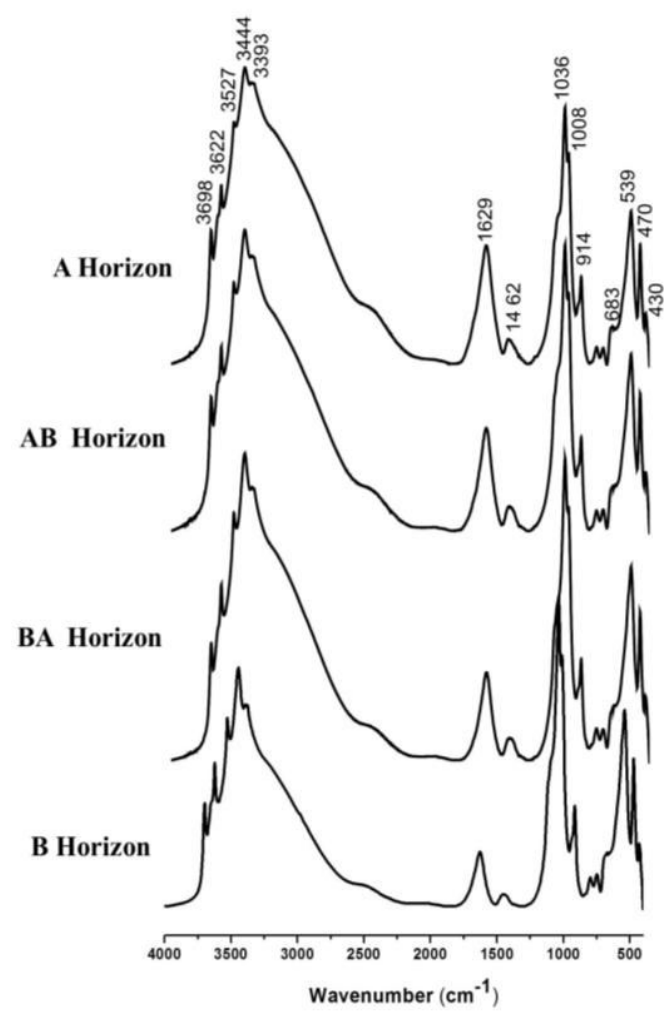

Figure 1. FTIR spectra from (a) soil and (b) HA samples

The qualitative characteristics of soil and HA obtained by FTIR (Figure 1) indicates no changes in the chemical composition between the horizons ( $A, A B, B A$ and $B)$. Thus, these results suggest that the spectroscopic analysis by FTIR of $A, A B, B A$ and $B$ horizons, from Latossolo Bruno cannot contribute to its pedological classification.
The current Brazilian Soil Classification System, developed and adapted by the soil survey staff of Embrapa and its partners, ${ }^{4}$ is believed to cover all known soils within the Brazilian territory. It was published in $1999^{17}$ and it has been updated over the years. ${ }^{4}$ Presently, it is structured in categorical levels and classes and it is based on attributes and diagnostic horizons. ${ }^{4}$

Table 1. Signals of FTIR spectra

\begin{tabular}{|c|c|}
\hline Frequency $\left(\mathrm{cm}^{-1}\right)$ & Description \\
\hline 3697 & $\mathrm{O}-\mathrm{H}$ stretching of kaolinite \\
\hline 3622 & $\mathrm{O}-\mathrm{H}$ stretching of kaolinite \\
\hline 3528 & $\mathrm{O}-\mathrm{H}$ stretching of gibbsite \\
\hline 3445 & $\mathrm{O}-\mathrm{H}$ stretching of gibbsite \\
\hline 3393 & $\begin{array}{l}\text { Axial deformation in phenolic } \mathrm{O}-\mathrm{H} \text { group, with aliphatic } \mathrm{O}-\mathrm{H} \text { contribution, } \\
\mathrm{H}_{2} \mathrm{O} \text { and amine }\end{array}$ \\
\hline 1630 & Aromatic $\mathrm{C}=\mathrm{C}$ vibrations and asymmetrical stretching $\mathrm{C}=\mathrm{O}$ of $\mathrm{COO}^{-}$ \\
\hline 1462 & Asymmetric angular $\mathrm{C}-\mathrm{H}$ deformation of the $-\mathrm{CH}_{2}$ and $-\mathrm{CH}_{3}$ groups \\
\hline Rev. Virtual Quim. & Vol 9| |No.5| |1813-1824| \\
\hline
\end{tabular}


$1423 \quad \mathrm{O}-\mathrm{H}$ phenolic and deformations of aliphatic groups

1047 C-O polysaccharides axial deformation and axial deformation Si-O in kaolinite or $\mathrm{O}-\mathrm{H}$ deformation in gibbsite

1035 Si-O-Si in plane stretching modes of kaolinite, O-H vibrations of gibbsite, and $\mathrm{C}-\mathrm{O}$ stretching of polysaccharides

1010 Angular O-H deformation in kaolinite and gibbsite, as well as Si-O-Si in plane stretching modes of kaolinite

915 Aromatic $\mathrm{C}-\mathrm{H}$ vibrations and aliphatic $-\mathrm{CH}_{2}-$, and also the vibration of $\mathrm{O}-\mathrm{H}$ groups in kaolinite

Angular deformation $\mathrm{C}-\mathrm{H}$ bonds, out of the plan aromatic rings, vibrational modes of the octahedra around $\mathrm{Al}$ ions of kaolinite, halloysite and gibbsite, $\mathrm{Si}-\mathrm{O}$ stretch of quartz, Si-O-Al translation of kaolinite, halloysite and $\mathrm{Al}-\mathrm{OH}$ of gibbsite

Angular deformation $\mathrm{C}-\mathrm{H}$ bonds, out of the plan aromatic rings, vibrational 747 modes of the octahedra around Al ions of kaolinite, halloysite and gibbsite, $\mathrm{Si}-\mathrm{O}$ stretch of quartz, Si-O-Al translation of kaolinite, halloysite and $\mathrm{Al}-\mathrm{OH}$ of gibbsite

Mineral impurities, $\mathrm{O}-\mathrm{H}$ stretching of gibbsite and Si-O stretch of quartz, 692 vibrations of the octahedra involving $\mathrm{Al}^{3+}$ ions, Si-O-Si deformations should also participate

Mineral impurities, $\mathrm{O}-\mathrm{H}$ stretching of gibbsite and Si-O stretch of quartz, 430 vibrations of the octahedra involving $\mathrm{Al}^{3+}$ ions, Si-O-Si deformations should also participate

The multivariate analysis by PCA and hierarchical cluster analysis (HCA) corroborate to the qualitative analysis. The PCA scores plot from soil samples is shown in Figure 2. The first principal component (PC1) and the second principal component (PC2), which explained 75.7 and $22.2 \%$ of the variation in the data, respectively, did not show a tendency to discriminate the soil samples based on horizons. Soil samples from the B horizon were separate from the others. Similar results were obtained by HCA (Figure 3). 
Carra, J. B. et al.

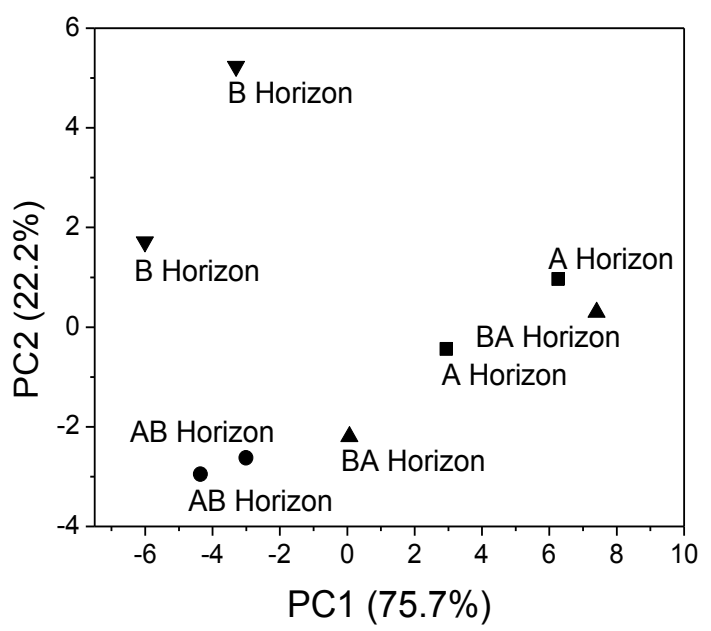

Figure 2. PCA scores plot (PC1 versus PC2) obtained with FTIR results of soil samples ( $\mathbf{\square})$ A horizon, $(\bullet)$ AB horizon, $(\mathbf{A})$ BA horizon and $(\boldsymbol{\nabla})$ B horizon, at the regions between 3731-3282 $\mathrm{cm}^{-1}, 1714-1543 \mathrm{~cm}^{-1}$ and $1238-400 \mathrm{~cm}^{-1}$ and base line correction

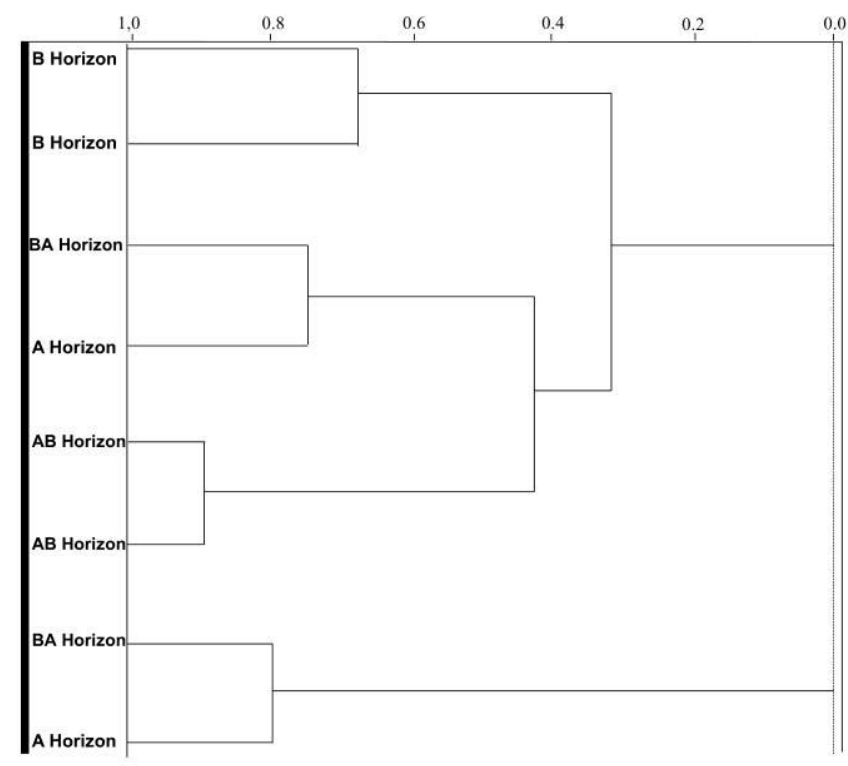

Figure 3. Dendrograms obtained by HCA for the FTIR results of soil samples

In the PCA and HCA, the $3731-3282 \mathrm{~cm}^{-1}$, $1714-1543 \mathrm{~cm}^{-1}$ and $1238-400 \mathrm{~cm}^{-1}$ region were selected because the other regions contained no relevant spectral information. In the PCA and HCA, the results were obtained with the application of the base line correction.

Similar results were obtained for HA. The PCA scores plot from HA samples is shown in
Figure 4. PC1 and PC2, which explained 80.1 and $12.9 \%$ of the variation in the data, respectively, did not show a tendency to discriminate the HA samples based on horizons. HA samples ( $A$ horizon, $A B$ horizon and $B A$ horizon) showed similarity. Similar results were obtained by HCA (Figure 5). 


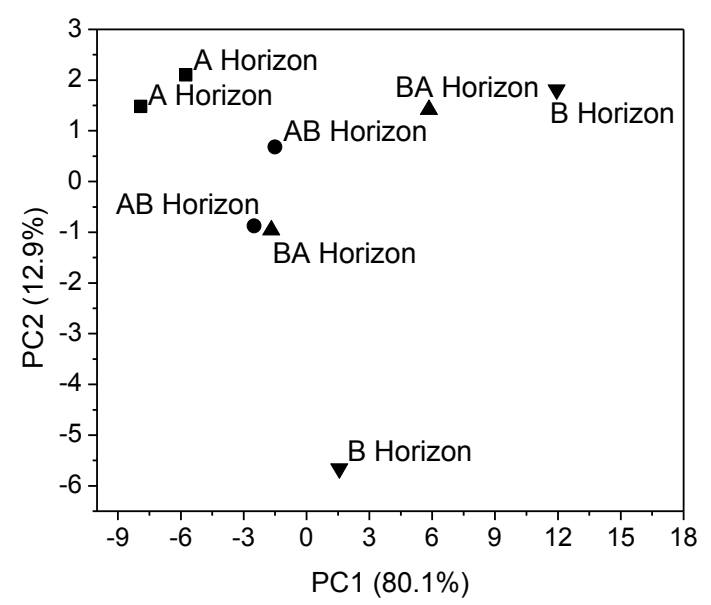

Figure 4. PCA scores plot (PC1 versus PC2) obtained with FTIR results of HA samples ( $\mathbf{\square})$ A horizon, $(\bullet)$ AB horizon, $(\mathbf{A})$ BA horizon and $(\boldsymbol{\nabla})$ B horizon, at the regions between 3741-2841 $\mathrm{cm}^{-1}$ and $1830-400 \mathrm{~cm}^{-1}$ and SNV

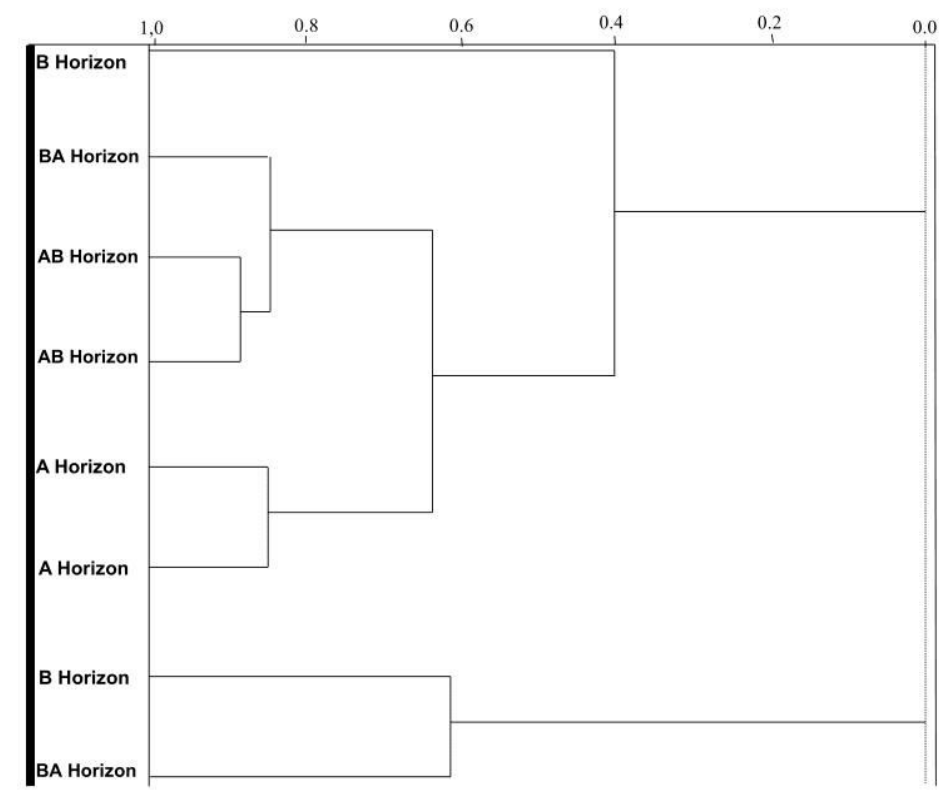

Figure 5. Dendrograms obtained by HCA for the FTIR results of HA samples

In the PCA and HCA, the $3741-2841 \mathrm{~cm}^{-1}$ and $1830-400 \mathrm{~cm}^{-1}$ region were selected because the other regions contained no relevant spectral information. In the PCA and $\mathrm{HCA}$, the results were obtained with the application of the SNV.

The pre-treatments, baseline correction and SNV, showed the best separation of soil samples and HA, respectively (Figures 2 and 4). The pre-treatment method, which is used to minimize light scattering problems, is very common in scans where the radiation is directly placed on the sample. ${ }^{18,19}$

Table 2 presents the total carbon (\%), $\mathrm{I}_{1630} / \mathrm{I}_{2920}$ and $\mathrm{E}_{4} / \mathrm{E}_{6}$ ratio results. 
Table 2. Total carbon (\%), $I_{1630} / I_{2920}$ and $E_{4} / E_{6}$ ratio results from $A, A B, B A$ and $B$ horizons

\begin{tabular}{|c|c|c|c|c|}
\hline \multirow{2}{*}{ Horizons } & \multirow{2}{*}{ Total Carbon (\%) } & \multicolumn{2}{|c|}{$\mathrm{I}_{1630} / \mathrm{I}_{2920}$} & \multirow{2}{*}{$E_{4} / E_{6}$} \\
\hline & & Soil & $\mathrm{HA}$ & \\
\hline A & $2.60 \pm 0.17$ & $1.09 \pm 0.04$ & $2.06 \pm 0.14$ & $2.42 \pm 0.12$ \\
\hline$A B$ & $2.29 \pm 0.00$ & $1.10 \pm 0.10$ & $1.97 \pm 0.47$ & $2.72 \pm 0.05$ \\
\hline BA & $1.66 \pm 0.10$ & $1.00 \pm 0.13$ & $2.81 \pm 1.26$ & $2.09 \pm 0.50$ \\
\hline B & $0.77 \pm 0.10$ & $0.95 \pm 0.00$ & $0.92 \pm 1.40$ & $3.30 \pm 0.07$ \\
\hline
\end{tabular}

The total carbon content of the samples varied from $2.60 \pm 0.17 \%$ in the $A$ horizon to $0.77 \pm 0.10 \%$ in the $B$ horizon (Table 1 ), showing a contribution of the crop residues and a lack of soil disturbance that kept residues concentrated at $\mathrm{A}$ horizon and not distributed along the soil profile. ${ }^{20}$ Similar results were observed by Silva et al. (2006), ${ }^{21}$ in a Red Oxisol under different uses and management systems, and by Dick et al. $(2006)^{22}$ for constructed soils from a coal mining area in southern Brazil. The gradual variation in carbon content with soil depth is according to the expected, since it diminishes with a depth.

Consequently, it is possible to state that despite the fact that the qualitative characteristics did not show significant differences between horizons, these differences were detected by quantitative analysis.

The aromaticity degree $\left(I_{1630} / I_{2920}\right)$ showed no gradual variation along the horizons, for the soil samples the highest and lowest values were observed for the $A B$ and $B$ horizons, respectively, and for the HA samples, the highest and lowest values were observed for BA and B horizons, respectively (Table 1).

The results obtained by the index proposed by Chefetz et al. (1996) ${ }^{12}$ for estimating the aromatic character of humic substances $\left(\mathrm{I}_{1630} / \mathrm{I}_{2920}\right)$, does not allow the classification of samples as the horizons. However Dick et al. (2006) ${ }^{22}$ showed that the FTIR aromaticity index $\left(I_{1620} / I_{2920}\right)$ can be a useful tool for the study of pedogenic and geological organic matter, in studies with a Plinthic Acrisol.

The $E_{4} / E_{6}$ ratio varied from $2.1 \pm 0.5$ to $3.30 \pm 0.07$, for $B A$ and $B$ horizons, respectively (Table 1 ). These results showed that the $E_{4} / E_{6}$ ratio did not show any relationship with depth. Similar result was observed by Miranda et al. (2007) $)^{23}$ in areas of native Atlantic forest developed on a Gleysol and Cambisol, and in abandoned plantations of eucalyptus of different ages on an Acrisol. This behavior was also observed in the variation of the aromaticity degree $\left(I_{1630} / I_{2920}\right)$ obtained by FTIR.

According to Kononova (1982), ${ }^{24}$ the $E_{4} / E_{6}$ ratio varies with the soil types. The difference observed among the values of $E_{4} / E_{6}$ determined in this work (2.1 to 3.30) and the values obtained by Canellas \& Façanha $(2004)^{25}$ from Ultisol samples (4.4 to 7.0) agree with Kononova's $(1982)^{24}$ statement. Although Santos et al. (2010) ${ }^{7}$ showed higher values for this ratio (5.3 to 10.0) for HA extracted from Oxisols.

The aromaticity degree $\left(I_{1630} / I_{2920}\right)$ and humification index $\left(E_{4} / E_{6}\right)$ are not effective in distinguishing between the horizons from Latossolo Bruno and thus cannot contribute in soil classification.

The linear regression between the indexes obtained by FTIR $\left(\mathrm{I}_{1630} / \mathrm{I}_{2920}\right)$, UV-visible $\left(\mathrm{E}_{4} / \mathrm{E}_{6}\right)$ and the total carbon content data gave a statistically significant correlation. The $R^{2}$ obtained between the $I_{1630} / I_{2920}$ from HA and $E_{4} / E_{6}$ was 0.9614 , and the $R^{2}$ between the $\mathrm{I}_{1630} / \mathrm{I}_{2920}$ from soil and the total carbon content presented was 0.9191 . 
This result indicates that the qualitative and quantitative characterization of the organic matter can be correlated, ensuring exact, accurate and consistent results about the compound in study. Furthermore, this result implies that the different indexes showed up correlated.

The high correlation between the $I_{1630} / I_{2920}$ and $E_{4} / E_{6}$ obtained by $H A$ characterization and the high correlation between the $\mathrm{I}_{1630} / \mathrm{I}_{2920}$ and the carbon content by soil

(A)

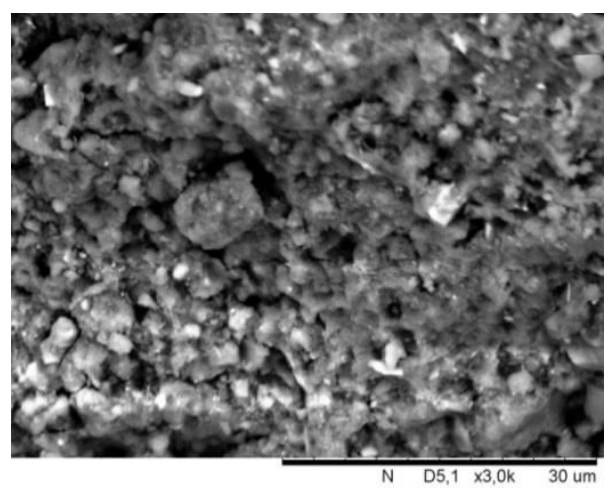

(C)

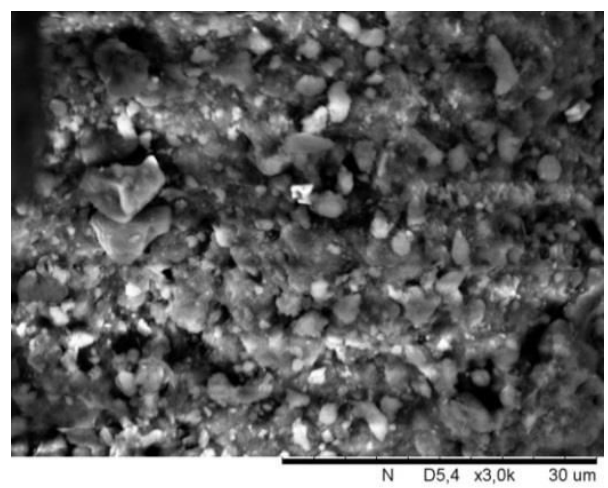

characterization indicated that data obtained by these techniques may lead to similar conclusions, evidencing the inapplicability of the indexes in the soil pedological classification.

SEM micrographs obtained from $A, A B, B A$ and $B$ horizons are shown in Figure 6. Second Velasco $(2013)^{26}$ SEM images are able to look at soil surfaces on microscopic levels and note distinct particle associations.

(B)

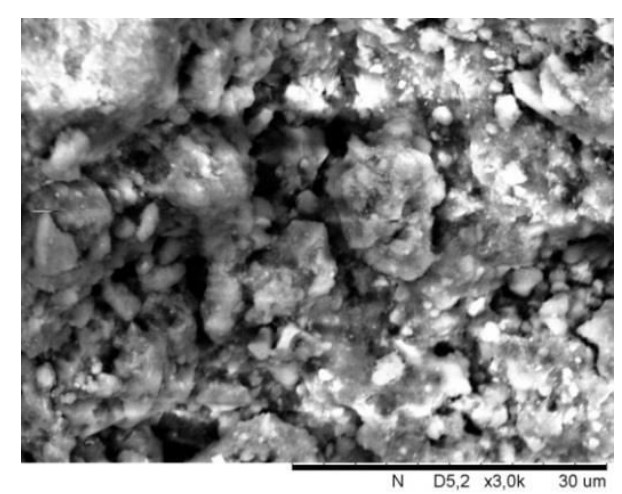

(D)

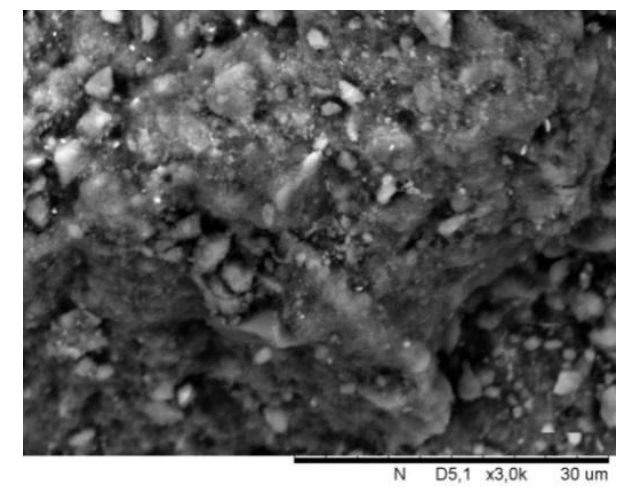

Figure 6. SEM photographs of soil samples from (A) A horizon (B) $A B$ horizon (C) BA horizon and (D) B horizon

SEM photographs did not allow the observation of differences in the soil aggregates from $A, A B, B A$ and $B$ horizons, and thus it can be inferred that under the conditions of analysis employed, SEM does not differentiate the Latossolo Bruno horizons.

\section{Conclusions}

The qualitative and quantitative characterization of the organic matter by FTIR and statistical tools did not show a tendency to discriminate the soil samples based on horizons. Thus, it can be concluded 
that the results obtained by spectroscopic techniques show high correlation and consequently may lead to similar conclusions, evidencing the inapplicability of the indexes in the soil pedological classification.

Finally, the results demonstrated in this paper by spectroscopic and SEM techniques should help us better understand the specific type of tropical soil, Latossolo Bruno, and despite the diversity of soils types, it can contribute to the understanding of Brazilian soils.

\section{Acknowledgements}

This work was supported by Conselho Nacional de Desenvolvimento Científico e Tecnológico (CNPq) Brazil, Coordenação de Aperfeiçoamento de Pessoal de Nível Superior (CAPES) and Fundação Araucária. We thank the Universidade Tecnológica Federal do Paraná (UTFPR), Pato Branco, Paraná, Brazil, for the support on chemical and spectroscopic analyzes and Central de Análises of UTFPR (Pato Branco, Paraná, Brazil), for the support on spectroscopic analyzes. We thank PhD Tangriani Simioni Assmann and $\mathrm{PhD}$ André Brugnara Soares from UTFPR (Pato Branco, Paraná, Brazil) for the soil samples. We thank PhD Elídia Aparecida Vetter Ferri for the collaboration with the SEM analysis and results.

\section{References}

${ }^{1}$ FAO. Soil Map of the World, Revised Edition, Wageningen: ISRIC, 1997. [Link]

${ }^{2}$ USDA. Soil Taxonomy: A Basic System of Soil Classification for Making and Interpreting Soil Surveys, 2. ed., Washington, DC, 1999. [Link]

${ }^{3}$ Isbell, R. F. The Australian Soil Classification, Revised Edition, CSIRO Publishing, Collingwood, 2002. [Link]

${ }^{4}$ EMBRAPA. Sistema brasileiro de classificação de solos, 3. ed. Brasília: EMBRAPA, 2013. [Link]
${ }^{5}$ Schaefer, C. E. G. R.; Gilkes, R. J.; Fernandes, R. B. A. EDS/SEM study on microaggregates of Brazilian Latosols, in relation to $P$ adsorption and clay fraction attributes. Geoderma 2004, 123, 69. [CrossRef]

${ }^{6}$ González-Pérez, M.; Torrado, P. V.; Colnago, L. A.; Martin-Neto, L.; Otero, X. L.; Milori, D. M. B. P.; Gomes, F.H. ${ }^{13} \mathrm{C}$ NMR and FTIR spectroscopy characterization of humic acids in spodosols under tropical rain forest in southeastern Brazil. Geoderma 2008, 146, 425. [CrossRef]

${ }^{7}$ Santos, L. M.; Simões, M. L.; Melo, W. J.; Martin-Neto, L.; Pereira-Filho E. R. Application of chemometric methods in the evaluation of chemical and spectroscopic data on organic matter from Oxisols in sewage sludge applications. Geoderma 2010, 155, 121. [CrossRef]

${ }^{8}$ Swift, R. S. In methods of soil analysis: chemical methods, part 3; Sparks, D. L., ed.; Soil Science Society America and American Society of Agronomy: Madison, Wisconsin, USA, 1996. [Link]

${ }^{9}$ Stevenson, F. J. Humus chemistry: genesis, composition, reactions, $2^{\text {nd }}$ ed., John Wiley, New York, USA, 1994.

${ }^{10}$ Merlin, N.; Lima, V. A.; Santos-Tonial, L. M. dos. Instrumental and experimental conditions for the application of fourier transform infrared analysis on soil and humic acid samples, combined with chemometrics tools and scanning electron microscopy. Journal of the Brazilian Chemical Society 2015, 26, 1920. [CrossRef]

${ }^{11}$ Chen, Y.; Senesi, N.; Schnitzer, M. Information provided on humic substances by $E_{4} / E_{6}$ ratios. Soil Science Society of America Journal 1977, 41, p. 352-358, 1977. [Link]

${ }^{12}$ Chefetz, B.; Hatcher, P. G.; Hadar, Y.; Chen, $Y$. Chemical and biological characterization of organic matter during composting of municipal solid waste. Journal of Environmental Quality 1996, 25, 776. [Link]

${ }^{13}$ Brinatti, A.; Mascarenhas, Y. P.; Pereira, V. P.; Partiti, C. S. M.; Macedo, A. Mineralogical characterization of a highly-weathered soil by the Rietveld Method. Scientia Agrícola 2010, 67, 454. [Link]

${ }^{14}$ Tivet, F.; Sá, J. C. M.; Lal, R.; Milori, D. M. B. P.; Briedis, C.; Letourmy, P.; Pinheiro, L. A.; 
Borszowskei, P. R.; Hartman, D. C. Assessing humification and organic $C$ compounds by laser-induced fluorescence and FTIR spectroscopies under conventional and no-till management in Brazilian Oxisols. Geoderma 2013, 207, 71. [CrossRef]

${ }^{15}$ Benites, V. M.; Mendonça, E. S.; Schaefer, C. E. R.; Martin-Neto, L. Caracterização dos ácidos húmicos extraídos de um latossolo vermelho-amarelo e de um podzol por análise termodiferencial e pela espectroscopia de absorção no infravermelho. Revista Brasileira de Ciência do Solo 1999, 23, 543. [CrossRef]

${ }^{16}$ Castellano, M.; Turturro, A.; Riani, P.; Montanari, T.; Finocchio, E.; Ramis, G.; Busca, G. Bulk and surface properties of commercial kaolins. Applied Clay Science 2010, 48, 446. [CrossRef]

${ }^{17}$ EMBRAPA. Sistema brasileiro de classificação de solos, 1 . ed. Brasília: EMBRAPA, 1999.

${ }^{18}$ Braga, J. W. B; Poppi, R. J. Validação de modelos de calibração multivariada: uma aplicação na determinação de pureza polimórfica de carbamazepina por espectroscopia no infravermelho próximo. Química Nova, 2004, 27, 1004. [CrossRef]

${ }^{19}$ Souza, D. M.; Madari, B. E.; Guimarães, F. F. Aplicação de técnicas multivariadas e inteligência artificial na análise de espectros de infravermelho para determinação de matéria orgânica em amostras de solos. Química Nova 2012, 35, 1738. [CrossRef]
${ }^{20}$ Franzluebbers, A. J. Soil organic matter stratification ratio as an indicator of soil quality. Soil \& Tillage Research 2002, 66, 95. [CrossRef]

${ }^{21}$ Silva, M. A. S.; Mafra, A. L.; Albuquerque, J. A; Rosa, J. D.; Bayer, C.; Mielniczuk, J. Propriedades físicas e teor de carbono orgânico de um argissolo vermelho sob distintos sistemas de uso e manejo. Revista Brasileira de Ciência do Solo 2006, 30, 329. [Link]

${ }^{22}$ Dick, D. P.; Knicker, H.; Ávila, L. G.; Inda Junior, A. V.; Giasson, E.; Bissani, C.A. Organic matter in constructed soils from a coal mining area in southern Brazil. Organic Geochemistry 2006, 37, 1537. [CrossRef]

${ }^{23}$ Miranda, C. C.; Canellas, L. P.; Nascimento, M. T. Caracterização da matéria orgânica do solo em fragmentos de mata atlântica e em plantios abandonados de eucalipto. Revista Brasileira de Ciência do Solo 2007, 31, 905. [Link]

${ }^{24}$ Kononova, M. M. Materia orgánica del suelo: su naturaleza, propiedades y métodos de investigación. Barcelona: Oikos-tau, 1982.

${ }^{25}$ Canellas, L. P.; Façanha, A. R. Chemical nature of soil humified fractions and their bioactivity. Pesquisa Agropecuária Brasileira 2004, 39, 233. [CrossRef]

${ }^{26}$ Valesco, E. S. Scanning Electron Microscope (SEM) as a means to determine dispersibility. Ames: lowa State University, 2013. [Link] 